\title{
Chia (Salvia hispanica L.) Seeds Phytochemicals, Bioactive Compounds, and Applications: A Review
}

\author{
Joseph Wambua Nyingi and Monica Mburu
}

\section{ABSTRACT}

\begin{abstract}
With the increased global public health awareness, there is an increase in ultimatum calls for functional foodstuff with various health impacts. The utilisation of therapeutic foodstuff to avert illnesses like obesity, diabetes, and heart disease is obtaining motion among people. Chia seeds are dietary and medicinal species used as a herb in the ancient period by Aztec and Mayan communities. Chia is receiving scientific attention in the present time and is a non-conventional seed that has been recognised as a novel food. It is a customary food in Southern and Central America. It contains large amounts of phytochemicals and proteins, making it more consumed worldwide for its numerous health benefits to sustain healthy serum fat levels. These seeds contain polyunsaturated omega-3 fatty acids with antiinflammatory effects, promote cognitive performance, and lower cholesterol levels. Caffeic acid found in the seeds has antioxidant compounds that protect the body from free radicals, cancer and contains anti-ageing properties. Fibres are present in high concentrations, are connected with lowering inflammation, controls bowel movement, and reduces cholesterol levels. Chia seeds contain the nutritional value that aid in disease control, such as diabetes, hypertension, cancer, obesity, and heart disease. The presence of omega-6 and omega-3 present in chia seed and active compounds makes the chia seed contain crucial health benefits. Nevertheless, the efficacy and safety of natural food require validation by numerous scientific research and studies. Nowadays, most species are utilised worldwide for their nutritional characteristics and beneficial impacts on human health. The review summarises the recent information on chia seed, emphasising the phytochemicals, bioactivities, and applications.
\end{abstract}

Keywords: Applications, Bioactive compounds, Chia seeds, Phytochemicals.

\author{
Submitted : September 23, 2021 \\ Published : November 20, 2021 \\ ISSN: $2684-1827$ \\ DOI: $10.24018 /$ ejfood.2021.3.6.381 \\ Joseph Wambua Nyingi* \\ Institute of Food Bioresource Technology, \\ Dedan Kimathi University of Technology, \\ Kenya. \\ (e-mail: josenyingi@gmail.com) \\ Monica Mburu \\ Institute of Food Bioresource Technology, \\ Dedan Kimathi University of Technology, \\ Kenya. \\ (e-mail: monica.mburu@dkut.ac.ke)
}

*Corresponding Author

\section{INTRODUCTION}

Chia (Salvia hispanica $L$ ) is grown mainly for its' seeds. Chia plant produces purple and white flowers, which are three or four millimetres tiny and hermaphrodites. Chia seeds are herbaceous plants initially from southern Mexico and North Guatemala [1]. These are edible seeds of Salvia hispanica from the mint family (Lamiaceae). The species S. hispanica yields several dry indehiscent fruits referred to as seeds. The tiny white and black seeds were used with beans, amaranth, or corn as essential foods in the pre-Columbian period. Chia seeds are oval-shaped and contain a diameter of two millimetres with grey-black and white spots. The seeds absorb liquid when soaked and develop a mucilaginous coating that provides a distinctive gel texture to chia-based foods. Seed yield differs with cultivars and growing conditions [2]. The Salvia genus contains nearly nine hundred species widely distributed around various regions such as South and North America, Southern Africa, South-East Asia, and Central America. Chia has also been grown in areas like Bolivia, Columbia, Peru, Argentina, and Europe [3].

Chia seeds were used in the Mesoamerican culture, Mayas, and Aztecs, together with beans, amaranth, and corn to prepare food and medicines. In the pre-Columbian communities, chia seed was the subsequent key produce with beans on the first row. Chia was used for cosmetics, food, and religious rituals by the Aztec societies [1]. The seed colour may vary from grey, black, or black-spotted to white. Black and white chia seeds contain similar nutritional value. Black seeds have a protein content of $16.9 \%$ with $32.6 \%$ fibre content, while white seeds contain $16.5 \%$ protein content with $32.4 \%$ fibre content[4]. The white seeds appear larger, broader, and thicker, unlike the black ones.

Chia is a macro thermal short-day blossoming plant; hence planting should be conducted in late spring to allow flowering in the late summer or during fall at the high latitudes [5]. However, the probabilities of yielding seed are minimal as grain filling is hindered by frost. Due to this effect, early chia flowering plants were developed through genetic mutations [6]. The early flowering seeds produced variant results after analysis. The commercialised chia seed contains a coat colour that ranges from grey and black dotted to white. The two genotypes have been proven to have no variance in chemical composition [6]. Chia seeds are utilised to enhance the omega-3 fatty acid composition of animal products such as poultry, rabbit, or eggs [7]. Most secondary metabolites fit in the Chia seeds like flavonoids, and their polyphenols and glycosides are made up of caffeic acid building blocks, proanthocyanidins, and anthocyanin [8].

Chia has become a recognisable food due to its nutritional 
value, the chia seeds are rich in a linolenic acid (C18:3 n-3, ALA), vitamins, and phenolic acids [9]-[11]. The presence of fatty acids in chia seed is crucial for health, antimicrobial, and antioxidant activity [12]. Most species from the genus salvia have horticultural and homoeopathic importance as good sources of natural constituents like flavonoids such as myricetin, quercetin and kaempferol, and polyphenols chlorogenic and caffeic acid [13], [14].

Chia seeds contain functional purposes that help the digestive system, enhance skin health, support strong bones and muscles, and help reduce heart illnesses, among other diseases [15]. The seed has no mycotoxins and gluten [16]. Lately, discoveries concerning the nutritional properties, phytochemical, bioactivities, and its application have been conducted. This study aims to bring out the information on phytochemicals focusing on the bioactivities and application of chia seeds.

\section{CHIA SEed PHYTOCHeMicals}

Numerous active components, phenolic components, and vital fatty acids are present in chia seeds. The active components include Myricetin, Kaempferol, Quercetin, caffeic acid, Omega-3, and Omega-6 [2], [17]. The concentrations of these active compounds may vary due to cultivation regions. The environmental variations, climate changes, nutrient availabilities, cultivation year, or soil conditions affect the composition of phytochemicals [18]. Chia seed has high-fat content (30-33\%), proteins (15-25\%), dietary fibre (18-30\%), carbohydrates (26-41\%), vitamins, antioxidants, and minerals [19].

Chia seeds contain majorly polyunsaturated fatty acids (linoleic acids and $\alpha$-linolenic acids) [20]. Chia seed has 39\% oil which contains $19 \%$ omega- 6 and $68 \%$ omega- 3 fatty acid [21]. Temperature decreases the protein content [22]. At a low elevation attitude, the saturated fat content increase at high temperatures. The developmental stage influences the chemical composition of chia seed, where the linolenic acid tends to decrease by $23 \%$ from the early to mature stage while increasing linoleic acid and lignin content [22].

\section{A. Flavonoids}

Flavonoids are an essential natural product class; they are commonly secondary metabolites with a polyphenolic structure [23], [24]. The polyphenol group consists of a fifteen-carbon element with two benzene rings. Flavonoids contain biochemical functions like antiviral, antioxidant, hepatoprotective, antibacterial, anti-inflammatory, and anticancer properties [25], [26]. These compounds are present in chia seeds, and microbial infection effects increase their synthesis. The most common flavonoids in Chia seeds are Myricetin, Quercetin, and Kaempferol [2], [14].

Naturally, flavonoids compounds are found in several parts of the plant and can be extracted. Flavonoids are mainly used by plants for growth and protection against plaques [27]. The flavonoids can be categorised into different subgroups depending on the carbon of the $\mathrm{C}$ ring on which the $\mathrm{B}$ ring is linked and the level of oxidation and saturation of the $\mathrm{C}$ ring. The flavonoids subgroups are isoflavones, neoflavanoids, flavonols, Chalcones, Anthocyanins, and flavones [23]. The subgroup flavones are the most present flavonoid in Chia, and
Its subclasses consist of Quercetin, Myricetin, Kaempferol, Rutin, and Morin[23].

\section{B. Myricetin}

Chia seed contains myricetin compounds. Myricetin is among the flavonoid group of phenolic compounds containing antioxidant features. This compound is produced from the central element taxifolin via intermediate dihydromyricetin and later processed into laricitrin and eventually syringetin, which are flavonoid categories [28]. Antioxidants are molecules that aid in protective effects against diseases such as cardiovascular disease and cancer. Myricetin induces the enzyme glutathione S-transferase which protects cells against oxidative stress by inhibiting free radicals from attacking the cells [29].

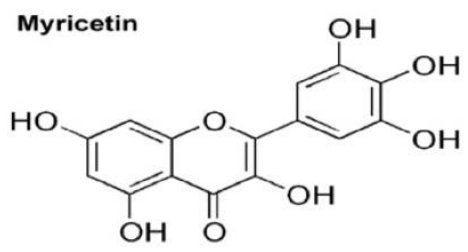

Molar mass: 318.2351

Formula: $\mathrm{C}_{15} \mathrm{H}_{10} \mathrm{O}_{8}$

\section{1) Chemical structure of Myricetin}

Myricetin undergoes autoxidation, making it to be a prooxidant. In the presence of cyanide, autoxidation occurs, producing superoxide, a by-product characterised by causing cellular damage[30]. Myricetin functions as a pro-oxidant because it can raise hydroxyl radicalisation through the reaction of hydrogen peroxide and iron ions. The resulting radicals are connected with DNA degradation [31]. Myricetin can function as a blocking agent in contrast with glutathione reductase accountable for stimulating glutathione, a scavenger for peroxides and free radicals [32]. Myricetin compounds contain anticarcinogenic properties as it inhibits polycyclic aromatic hydrocarbons that causes skin tumorigenicity [33].

\section{Quercetin}

Chia seed has quercetin flavonoid compounds which is a naturally occurring pigment. Quercetin is flavonol in the polyphenols group and has an unpleasant flavour. It is a common component in dietary complements, foods, and beverages [31]. Phenylalanine is changed into 4-coumaroyl$\mathrm{CoA}$ during the phenylpropanoid pathway. One molecule is added into the other three malonyl-CoA molecules resulting in the formation of tetrahydroxychalcone using 7, 2'dihydroxy-4'-methoxyisoflavanol synthase [34]. Chalcone isomerase converts tetrahydroxychalcone into naringenin which is later changed into eriodictyol by the use of 3'hydroxylase flavonoid. Eriodictyol, by using flavanone 3hydroxylase, is converted into dihydroquercetin, which is transformed into Quercetin using the flavonol synthase enzyme [35]. 
<smiles>O=c1c(O)c(-c2ccc(O)c(O)c2)oc2cc(O)cc(O)c12</smiles>

Molar mass: $302.236 \mathrm{~g} / \mathrm{mol}$

Formula: $\mathrm{C}_{15} \mathrm{H}_{10} \mathrm{O}_{7}$

\section{1) Chemical structure of Quercetin}

Quercetin has antioxidant properties that help reduce the oxidation of low-density lipoprotein by scavenging free radicals and can help prevent several diseases [36], [37]. The antioxidant action of Quercetin allows for lipid peroxidation inhibition such that unsaturated fatty acids are not converted into free radicals [31]. Quercetin also helps lower inflammation through scavenging free radicals. Free radicals are responsible for the activation of cytokines which are likely to cause inflammatory illnesses [38], [39].

\section{Kaempferol}

It is a natural flavonoid found in several plant foods, such as chia seeds. It is a tetrahydroxyflavone molecule in which its four hydroxy groups are situated at positions 3, 5, 7, and 40 and appears yellow transparent solid portraying a melting point of 276-278 ${ }^{\circ} \mathrm{C}$ [29], [40]. This flavonoid is soluble in hot alcohol products such as ethanol [31]. Phenylalanine can be transformed into 4-coumaroyl-CoA, where it syndicates with 3 malonyl-CoA molecules to generate naringenin chalcone with the aid of the enzyme chalcone synthase [41], [42]. Naringenin is produced from naringenin chalcone to generate dihydrokaempferol, which is later acted upon to produce Kaempferol. Kaempferol has similar functional properties, just like other flavonoids [43].<smiles>O=c1c(O)c(-c2ccc(O)cc2)oc2cc(O)cc(O)c12</smiles>

Molar mass $286.23 \mathrm{~g} / \mathrm{mol}$

Formula: $\mathrm{C}_{15} \mathrm{H}_{10} \mathrm{O}_{6}$

\section{1) Chemical structure for Kaempferol}

Kaempferol exhibit numerous pharmacological properties, among them antioxidant, anti-inflammatory, antitumor, antimicrobial, neuroprotective, cardioprotective, and antidiabetic activities [44].

Epidemiological researches have shown that a high intake of Kaempferol is linked with decreased occurrences of different types of cancers such as liver, skin, stomach, pancreas, colon, ovary, and bladder [45], [46]. Consumption of kaempferol rich foods like Chia seeds and associated applications in cancer therapy is getting enormous attention amongst the research community [47]. In order to overcome Kaempferol low bioavailability studies [48] suggest should be combined with Quercetin to elevate its bioavailability, thus improving its bio-efficacy.

\section{E. Caffeic Acid}

Caffeic Acid (CA) is produced through the secondary metabolism of foods and contains hydroxycinnamic acid present in the human diet [49]. Caffeic acid is present in simple monomers such as sugar esters, amides, organic acids, and complex forms such as glycosides, dimers, or trimers [31]. Caffeic acid is crucial in the biological and chemical chia seed viewpoint [3], [50]. It consists of a dihydroxyphenyl group connected with acrylic acid, which forms the molecular structure of metabolites found in the Lamiaceae family [51]. It can be categorised as hydroxycinnamic acid, often connected to quinic acid in various points, producing metabolite clusters known as caffeoylquinic acids, where chlorogenic acid is the most plentiful polar extract of chia seeds [8], [50]. In the chia seed metabolome, monomers of caffeic acid building blocks are present. Ultra-high performance liquid chromatography (UHPLC) has been applied to separate caffeic acid monomers from the chia seeds [8]. The authors [8] discovered a high concentration of caffeic acid $(0.0274 \mathrm{mg} / \mathrm{g})$ higher than reported for blueberry $(0.0216 \mathrm{mg} / \mathrm{g})$, papaya $(0.0159 \mathrm{mg} / \mathrm{g})$, and mango $(0.0274 \mathrm{mg} / \mathrm{g})$, but lower than the reported concentration of peach. According to [25] Caffeic acid from Chia seeds contains antioxidant, anticarcinogenic, anti-hypertensive, neuron-protective effects and anti-inflammatory activity.<smiles>O=C(O)/C=C/c1ccc(O)c(O)c1</smiles>

Molar mass: $180.16 \mathrm{~g} / \mathrm{mol}$

Formula: $\mathrm{C}_{9} \mathrm{H}_{8} \mathrm{O}_{4}$

\section{1) Chemical structure of Caffeic acid}

\section{F. Chlorogenic}

Chlorogenic acid, abbreviated as CGA, is the ester of caffeic with quinic acid [52]. Recent studies have shown chia seeds to contain amounts of chlorogenic acid [53], [54].<smiles>O=C(/C=C/c1ccc(O)c(O)c1)OC1CC(O)(O)C[C@H](O)[C@H]1O</smiles>

Molar mass: $354.31 \mathrm{~g} / \mathrm{mol}$

Formula: $\mathrm{C}_{16} \mathrm{H}_{18} \mathrm{O}_{9}$

\section{1) Chemical structure of chlorogenic acid}

Chlorogenic acid has various potential health effects, most notably reducing blood pressure [55] and weight management [56], [57]. According to [58] chlorogenic acid improves mood, reduces the risk of infection, and lowers blood sugar levels. Chlorogenic acid mainly applies its effects by hindering the alpha-glucosidase enzyme in charge of breaking glucose and carbohydrates during digestion [59], [60]. 
Chia seeds are believed to contain other active compounds such as rosmarinic acid, cinnamic, gallic, and isoflavones such as glycitein, genistein, and daidzein [3]. Most of the flavonoids found in chia seed have been proven through researches to have anticarcinogenic, anti-hypersensitive, and neuron protective activities [31]. Chia seed contains antioxidants and no toxic mycotoxins present.
[61] They analysed Chia seeds antioxidant activity, total phenolic content, and quantification of the phenolic compounds using Ultra-High-Performance Liquid Chromatography. Through this method, major phenolic compounds were measured; caffeic acid, rosmarinic, and daidzein [50]. All the Phenolic compounds in Chia seeds are presented below.

TABLE I: PHENOLIC PHYTOCHEMICALS FROM SALVIA HISPANICA (CHIA) SEEDS

\begin{tabular}{|c|c|c|c|c|}
\hline Phenolic compounds & Quantification & Origin & Analytical technique used & References \\
\hline \multicolumn{5}{|l|}{ Flavonoids } \\
\hline \multirow{2}{*}{ Myricetin } & $0.115-0.121 \mathrm{mg} / \mathrm{g}$ & Tzotzol and Iztac (Ecuador) & HPLC & {$[62]$} \\
\hline & $3.1 \times 10^{-3} \mathrm{~mol} / \mathrm{kg}$ & I.m. (West lafayette, US) & TLC, GLC and UV & [63] \\
\hline \multirow{4}{*}{ Quercetin } & $0.17 \mu \mathrm{g} / \mathrm{g}$ & I.m. (Sao Paulo, Brazil) & UPLC & [63] \\
\hline & $0.007-0.006 \mathrm{mg} / \mathrm{g}$ & Tzotzol and Iztac (Ecuador) & HPLC & [62] \\
\hline & $0.150-0.268 \mathrm{mg} / \mathrm{g}$ & Jalisco and Sinaloa (Mexico) & HPLC & [14] \\
\hline & $0.2 * 10^{-3} \mathrm{~mol} / \mathrm{kg}$ & I.m. (West lafayette, US) & TLC, GLC and UV & {$[63]$} \\
\hline \multirow{3}{*}{ Kaempferol } & $0.025-0.024 \mathrm{mg} / \mathrm{g}$ & Tzotzol and Iztac (Ecuador) & HPLC & [62] \\
\hline & $0.006 \mathrm{mg} / \mathrm{g}$ & Chionacalyx (Mexico) & UHPLC & [8] \\
\hline & $0.360-0.509 \mathrm{mg} / \mathrm{g}$ & Jalisco and Sinaloa (Mexico) & HPLC & [14] \\
\hline \multicolumn{5}{|l|}{ Caffeic acids derivatives } \\
\hline \multirow{5}{*}{ Caffeic acids } & $0.030 \mathrm{mg} / \mathrm{g}$ & I.m. (Sao Paulo, Brazil) & UPLC & [63] \\
\hline & $0.139-0.1490 \mathrm{mg} / \mathrm{g}$ & Tzotzol and Iztac (Ecuador) & HPLC & [62] \\
\hline & $0.003-0.006 \mathrm{mg} / \mathrm{g}$ & Jalisco and Sinaloa (Mexico) & HPLC & [14] \\
\hline & $6.6 * 10^{-3} \mathrm{~mol} / \mathrm{kg}$ & m. (West lafayette, US) & TLC, GLC and UV & [63] \\
\hline & $\mathrm{T}$ & & & \\
\hline \multirow{4}{*}{ Chlorogenic acid } & $0.004 \mathrm{mg} / \mathrm{g}$ & I.m. (Sao Paulo, Brazil) & UPLC & [63] \\
\hline & $0.226-0.218 \mathrm{mg} / \mathrm{g}$ & Tzotzol and Iztac (Ecuador) & HPLC & {$[62]$} \\
\hline & $0.102-0.045 \mathrm{mg} / \mathrm{g}$ & Jalisco and Sinaloa (Mexico) & HPLC & [14] \\
\hline & $0.9267 \mathrm{mg} / \mathrm{g}$ & $\begin{array}{l}\text { Cnionacalyx } \\
\text { (Mexico) }\end{array}$ & UHPLC & [8] \\
\hline Rosmarinic acid & $0.9267 \mathrm{mg} / \mathrm{g}$ & Chionacalyx (Mexico) & UHPLC & {$[8]$} \\
\hline Ferulic acid & $\mathrm{T}$ & Chionacalyx (Mexico) & UHPLC & [8] \\
\hline
\end{tabular}

\section{Nutritional COMPOSITION OF CHIA SEEDS}

\section{A. Protein Content}

The protein content of chia seed varies regarding the place of growth, and agronomic factors can range between $15 \%$ to 23\% [53], [64]-[66]. Chia seeds (per 100 g) have more proteins $(16.54 \mathrm{~g})$ than other cereals like oats $(13.6 \mathrm{~g})$, wheat $(11.8 \mathrm{~g})$, barley $(11.5 \mathrm{~g})$, corn (11.1 g) and rice (6.8 g) [53], [67], [68]. Chia seeds are an excellent source of essential amino acids that have significant benefits to the body [67], [69]. Chia seeds do not have gluten content, making them more valuable to patients suffering from celiac illnesses [1], [53]. Food rich in protein is recommended to individuals who need to lose weight. Chia seed comprises 20 amino acids where 8 of which were associated with the generation of plant phospholipids connected with high concentrations of polyunsaturated fatty acids[50], [70].

Globulin makes about $52 \%$ of the total amino acids in Chia seeds, making it the most abundant protein with the most $7 \mathrm{~s}$ and $11 \mathrm{~s}$ proteins and a molecular size range of 15 to $50 \mathrm{kDa}$ [50]. The chia seeds have a good balance of non-essential and essential amino acids[67].

A high intake of proteins has been shown to lower appetite and decrease obsessive food obsessive thought by $60 \%$ and temptation of the night snacking by $50 \%$ [71], [72]. Chia seeds are a rich source of proteins, especially for persons who consume little or no animal products.

The composition of amino acids in Chia seeds is shown in the table below.
TABLE II: AVERAGE AMINO-ACID COMPOSITION OF CHIA SEED

\begin{tabular}{cccc}
\hline Amino acid & $\begin{array}{c}\text { Grams/100 } \\
\text { grams }\end{array}$ & Amino acid & $\begin{array}{c}\text { Grams/100 } \\
\text { grams }\end{array}$ \\
\hline Serine & 1.05 & Threonine & 0.709 \\
Tyrosine & 0.563 & Glutamic acid & 3.5 \\
Arginine & 2.14 & Isoleucine & 0.801 \\
Cystine & 0.407 & Tryptophan & 0.436 \\
Leucine & 1.37 & Lysine & 0.970 \\
Proline & 0.776 & Methionine & 0.588 \\
Aspartic acid & 1.69 & Histidine & 0.531 \\
Glycine & 0.943 & Valine & 0.95 \\
Alanine & 1.044 & Phenylalanine & 1.02 \\
\hline
\end{tabular}

Source: USDA National Nutrient Database for Standard Reference Release $28,2018$.

\section{B. Dietary Fibre}

Chia contains high levels of fibre that range between $34 \mathrm{~g}$ to $40 \mathrm{~g}$ of dietary fibre in every 100 -gram serving. On the basis of their phytochemicals, dietary fibres are categorised into Insoluble fibre, which holds the highest percentage of about $85 \%$ to $90 \%$, and soluble fibre holds about $7 \%$ to $15 \%$ [21], [73]. The fibre present in the chia seed lowers the risk of various diseases such as type-2 diabetes, stroke, hypertension, hyperlipidaemia, myocardial infarction, hyperglycaemia, coronary heart disease and several types of cancers [14], [53]. The high amount of fibre consumed in a diet also reduces hunger experiences. As per the American Dietetic Association, dietary fibre from Chia has been shown to have health benefits for good health maintenance and prevention of diseases [53]. The fibre is analysed for its insoluble constituents, which are utilised as a suspending agent, emulsifier, and foam stabiliser for food and pharmaceutical functions because of its physical characteristics, water-holding ability, and viscosity [74]. Chia 
seed dietary fibre is between $34 \mathrm{~g}$ and $40 \mathrm{~g}$ per $100 \mathrm{~g}$, which is an equivalent of $100 \%$ of the adult population daily recommendation and much higher than other grains and vegetables like amaranth, Quinoa, and flaxseed [53], [75]. Chia holds $5 \%$ to $10 \%$ mucilage, a soluble fibre [76], [77]. Chia seed insoluble fibre can retain water during hydration, offering bulk and prolonging the gastrointestinal transit period, raising blood sugar levels, and reducing insulin resistance [74].

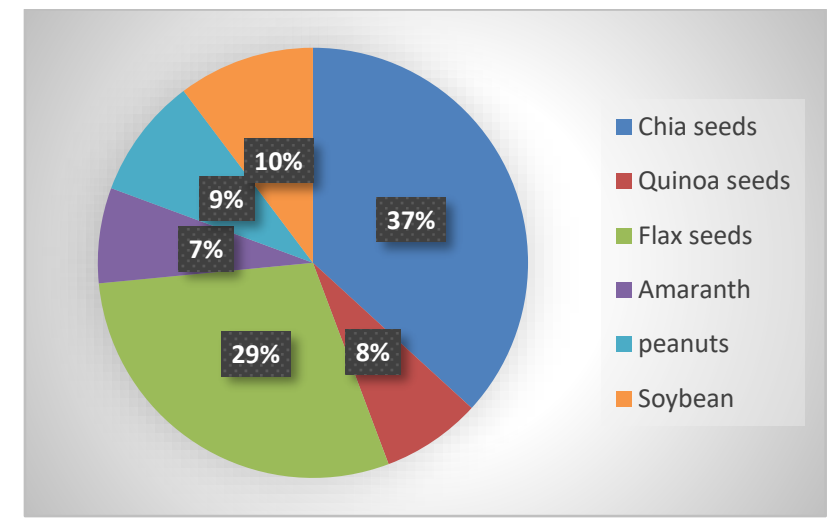

Fig. 1. The dietary fibre content of various food products.

Source: USDA National Nutrient Database for Standard Reference Release $28,2018$.

\section{Minerals and Vitamins}

Minerals such as calcium, magnesium, phosphorus, and potassium are present in chia seeds. Chia comprises such vitamins as A, B, E, K, D, B1, B2, and niacin [54], [78]. Research has demonstrated Chia to have more mineral content than corn, rice, oats, and wheat, with 2.4 and 6 times higher than liver and iron spinach, respectively [79]. Chia contains 4 times more potassium, 6 times the calcium, and 11 more phosphorus than $100 \mathrm{~g}$ of milk [80]. Table III below shows the average minerals and vitamin content of chia seeds.
TABLE III: Average MineRals AND Vitamin CONTENT OF CHIA SEEDS

\begin{tabular}{|c|c|c|c|}
\hline Vitamins & $\begin{array}{c}\text { Per } 100 \\
\text { grams }\end{array}$ & Minerals & $\begin{array}{c}\text { Per } 100 \\
\text { grams }\end{array}$ \\
\hline $\begin{array}{c}\text { Vitamin-E } \\
\text { (alpha- } \\
\text { tocopherol) (mg) }\end{array}$ & 0.50 & Iron (mg) & 7.72 \\
\hline Vitamin-A (IU) & 54 & Potassium (mg) & 407 \\
\hline Niacin (mg) & 8.83 & Zinc (mg) & 4.58 \\
\hline Thiamine (mg) & 0.62 & Magnesium (mg) & 335 \\
\hline $\begin{array}{c}\text { Vitamin C, Total } \\
\text { ascorbic acid } \\
(\mathrm{mg})\end{array}$ & 1.6 & Phosphorus (mg) & 860 \\
\hline Riboflavin (mg) & 0.17 & Sodium (mg) & 16 \\
\hline Folate, total $(\mu \mathrm{g})$ & 49 & Calcium (mg) & 631 \\
\hline Folate, food $(\mu \mathrm{g})$ & 49 & Copper (mg) & 0.924 \\
\hline Vitamin B- 12 & 0 & $\begin{array}{l}\text { Manganese (mg) } \\
\text { Selenium (mg) }\end{array}$ & 2.72 \\
\hline
\end{tabular}

Source: USDA National Nutrient Database for Standard Reference Release 28, 2018.

\section{Total Fats}

Chia seeds have an average of $30.74 \%$ of total lipids [78]. It is an excellent source of alpha-linolenic fatty acids, an omega- 3 fatty acid that promotes low omega- 6 to the omega3 fatty acid ratio related to lowered risks of chronic conditions such as inflammatory conditions, heart, and cancer [74]. Chia seed oil has phenolic components such as carotenoids, phytosterols, and tocopherols linked with antioxidant action crucial in oil deterioration because of lipid oxidation [81]. The omega-3 fatty acid present in chia seed helps avert dietrelated chronic illnesses [82]. Alpha-linolenic acid content is above $50 \%$ of all fatty acid; hence chia seed is a natural origin of omega-3, crucial in human health and nutrition [82]. The percentage composition of fatty acids utilising the positive ion easy ambient sonic-spray ionisation mass spectrometry method includes palmitic (7.07\%), $\alpha$-linolenic (62.8\%), linoleic $(18.23 \%)$, oleic $(7.04 \%)$, and stearic (3.36\%) [19]. The fat composition can be significantly affected by the extraction process and the geographical region. According to [65] Chia seeds are highly concentrated with omega- 3 fatty acids $(68 \%)$ compared to menhaden fish $(1.5 \%)$ and flaxseeds $(57.5 \%)$.

TABLE IV: SHOwING THE Average FATty ACID Composition OF CHIA SEEDS

\begin{tabular}{|c|c|c|c|c|c|}
\hline $\begin{array}{l}\text { Total saturated fatty acids } \\
\text { is (gram per } 100 \text { grams) }\end{array}$ & $3.330 \mathrm{~g}$ & $\begin{array}{l}\text { Total monounsaturated fatty } \\
\text { acids (gram per } 100 \text { grams) }\end{array}$ & $2.309 \mathrm{~g}$ & $\begin{array}{c}\text { Total polyunsaturated } \\
\text { fatty acids (gram per } 100 \\
\text { grams) }\end{array}$ & $23.665 \mathrm{~g}$ \\
\hline $22: 0$ & $0.32 \mathrm{~g}$ & $20: 1$ & $0.046 \mathrm{~g}$ & Cholesterol & $0 \mathrm{mg}$ \\
\hline 20:0 & $0.093 \mathrm{~g}$ & $18: 1$ & $2.203 \mathrm{~g}$ & Trans fatty acids & $0.140 \mathrm{~g}$ \\
\hline $18: 0$ & $0.912 \mathrm{~g}$ & $17: 1$ & $0.000 \mathrm{~g}$ & $18: 3$ & $17.80 \mathrm{~g}$ \\
\hline $17: 0$ & $0.063 \mathrm{~g}$ & $16: 1$ & $0.029 \mathrm{~g}$ & $18: 2 \mathrm{n}-6 \mathrm{c}, \mathrm{c}$ & $5.84 \mathrm{~g}$ \\
\hline $16: 0$ & $2.170 \mathrm{~g}$ & $14: 1$ & $0.030 \mathrm{~g}$ & $18: 2$ & $5.84 \mathrm{~g}$ \\
\hline $15: 0$ & $0.030 \mathrm{~g}$ & & & & \\
\hline $14: 0$ & $0.030 \mathrm{~g}$ & & & & \\
\hline
\end{tabular}

Source: USDA National Nutrient Database for Standard Reference Release 28, 2018.

\section{BIOACTIVE COMPOUNDS}

\section{A. Antioxidants and Antimicrobial Activity}

Chia seeds possess phenolic compounds with antioxidant activities [83], which can inactivate ABTS cation radicals. The antioxidant ability of the Chia seed has also been confirmed by [84]. The antioxidant phenolic nature in Chia is either in sugars in free form or by glycosidic linkages. According to [11] the glycosidic linkages are liable for the high solubility of Chia in water.

Phenolic compounds and antioxidants contain health promotion and protect from degenerative illnesses such as cancers, diabetes, or cardiovascular diseases [12], [85]. Chia seed comprises bioactive compounds such as Myricetin, Quercetin, Kaempferol, caffeic acids, and chlorogenic [78]. These polyphenols have high antioxidant abilities and help reduce lipid autoxidation levels [86]. This group of compounds is responsible for the antioxidant activity of Chia as they have the capabilities of scavenging free radicals, donating hydrogen, and chelating metal ions [19]. The flavones benzene rings scavenge the reactive oxygen species acts as electron and hydrogen are moved to hydroxyl, peroxynitrite, and peroxyl radicals that aid in stabilising them 
by producing stable flavonoid radicals [61], [63]. Rosmarinic and Caffeic acids [2], [8], [14] are the Chia phenolic compounds that have been demonstrated to help in the management and prevention of neurological conditions like epilepsy [9]. Some of the benefits of caffeic acid discovered in Chia include hypogenic activity and memory defensive effects. Antioxidant compounds lower chronic illness risks such as cancer and cardiovascular disease as they provide a protective effect against such disorders [31].

Cell structures and biomolecules experience oxidative stress because of reactive oxygen species activity and presence. Reactive oxygen species destroy lipids, proteins, and DNA. Steady accretion of such destruction causes the development of various illnesses and conditions such as cancer, thrombosis, diabetes, or persistent inflammation[61]. Flavonoids such as Myricetin, Quercetin, and Kaempferol can be used to scavenging reactive oxygen species and help chelate intracellular transition metal ions that generate reactive oxygen species [31]. The flavonoids can induce a glutathione S-transferase enzyme that helps protect cells against oxidative stress by preventing free radicals from attacking the cells [3]. Antioxidants present in chia seed help in fighting free radicals in the body. Free radicals lead to cell destruction and oxidative stress [19]. Feeding foods rich in antioxidants such as chia seed help in lowering free radical connected illnesses such as cancer, heart disease, or cognitive failure [87].

\section{B. Anti-inflammatory and Anticholesterolemic}

Inflammation is the body's normal response to injury or infections. At times inflammation is helpful to the body in fighting off harmful pathogens, which sometimes can lead to harm. This is common with chronic inflammation that is linked with the occurrence of cancer and heart diseases [88]. In most cases, there are no visible signs of chronic inflammation, but it can be examined by measuring blood inflammatory markers. Unhealthy lifestyle habits like smoking, poor diet and lack of exercise have been shown to increase the risk of chronic inflammation, while some healthy foods like incorporating Chia in diet proven to lower the inflammatory markers known as hs-CRP in the blood [89].

Chia seed contains anti-inflammatory effects as they can lower edemas caused by croton and carrageenan oil. Flavonoids such as Myricetin and Quercetin have shown antiinflammatory characteristics [90]. The anti-inflammatory features of flavonoids inhibit the generation of cytokines that is present during inflammation. The cytokines like interleukin-12 and interleukin-1 $\beta$ by down-managing of transcription aspects and mediators included in their generation. Flavonoids can inhibit inflammatory pathways such as kinases and inhibit the tumour necrosis factor-alpha function [91], [92]. Chronic inflammation causes health conditions such as heart disease and cancer. Caffeic acid found in chia seed help prevent inflammation in the body. Chia seed consumption assists in lowering inflammatory markers, which show the inflammatory disease presence. Quercetin lowers inflammation by scavenging free radicals that activate transcription factors that produce cytokines [93], [94].

High-density lipoprotein is linked with heart disease. Consumption of chia seed has indicated low serum cholesterol levels due to omega-3 fatty acids and dietary fibre. According to [95], chia protein and bioactive peptides inhibit important indicators of cholesterol production like 3hydroxy-3-methylglutaryl coenzyme A reductase (HMGCoA reductase) [96]. Chia intake has improved lipid redistribution linked with hepato-protection and cardioprotection. This is shown by rats obtaining hyperglycaemic, and hyperlipidaemic diet portrayed hindrances of enzyme stearoyl-CoA 9-desaturase in heart and liver [97].

\section{Anti-carcinogen}

Chia seed helps protect the cells from carcinogenic mutation [98]. Myricetin found in chia seed helps lower skin tumorigenicity risk triggered by polycyclic aromatic hydrocarbons such as benzo(a)pyrene, an extremely carcinogenic component [48], [98]. It will offer safeguard by preventing the development of skin tumours [28]. The genetic mutation is inhibited, resulting mutagenesis process caused by carcinogenic hydrocarbons becomes less efficient. Chia seeds have anticancer activity as it inhibits cancer generating cells. Chia seed extracts indicate that it contains the ability to treat cancer [48].

According to research [30] amongst the chia flavonoids, Myricetin has the most phenolic hydroxyl groups, showing its antioxidant potential as the number of hydroxyl groups increases. The myricetin flavonoids can avert cardiotoxic effects prompted by isoproterenol[30]. [99] established that men with higher myricetin intakes had a lower prostate cancer risk.

\section{Anti-hypersensitive}

High blood pressure has affected many individuals, becoming a risk factor [100]. Studies indicate that chia seeds can help lower blood pressure [89]. Rat studies have demonstrated that taking Chia seeds reduces certain risk factors such as belly fat, insulin resistance, inflammation, and triglycerides, raising good HDL cholesterol [101], [102]. Though, there was one human study that did not observe any enhancement in risk factors [103]. A few other studies show a significant reduction of blood pressure in persons with hypertension after consumption of chia seeds [89], [104].

Consumption of chia seed is encouraged for individuals suffering from hypertension [105], [106]. The existence of omega-3 fatty acids has been made known to reduce blood pressure levels [104]. Through enzymatic analysis, chia seeds have shown hypertension effects. Proteins hydrolysate present in Chia exhibits blocking the action of angiotensinconverting Enzyme-I, similarly done by synthetic angiotensin-converting Enzyme-I (ACE-I) inhibitors [106][108]. The hydrophobic protein residues of Chia contain similar synthetic ACE-I inhibitor action as they aid in blocking angiotensin II generation; replacing chia oil with other oils in a hypertension environment has been shown to help lower the blood pressure level hence more consumption of Chia promotes good health [109].

Chia seeds contain Quercetin which is an antioxidant that helps lower health complications development, including heart disease [110]. The chia seeds contain fibre that assists in lowering high blood pressure [17], [102]. Fibre present in chia help reduce insulin resistance and enhances blood glucose levels hence metabolic syndrome and type 2 diabetes risk are reduced [102]. Food containing chia seed generates a 
lower blood sugar response which prevents high blood sugar levels. Alpha-linoleic acids and eicosapentaenoic acids help produce essential biochemical compounds like leukotrienes, thromboxane, and prostaglandins applied for various physiological purposes. Omega-3 fatty acids have proven to have the ability to hamper sodium and calcium pathway dysfunctions which could lead to hypertension and enhance parasympathetic quality, safeguard ventricular arrhythmia, and heart rate variations [111].

Chlorogenic acids (CGAs) have an anti-hypertension effect, this has been proven by [111] through basic and clinical investigations. Mechanistically, CGAs metabolites lessen reactive oxygen species, which results in reduced risk of blood pressure through enhanced endothelial function and bioavailability of nitric oxide in the arterial vasculature [107], [108]. Chlorogenic acids have a promising pursuit in promoting healthy blood pressure.

\section{E. Weight Loss}

Chia seeds consist of a higher percentage of protein content recommended for persons who need to lose weight. One serving of chia seeds has $39 \%$ of the daily fibre allowance [112]. The soluble fibre and mucilage absorb water, causing the seeds to expound inside the stomach, making one feel full for longer hence less food consumed [112], [113]. In this way, chia seed helps one sustain their weight or lose some weight. With the rich dietary fibre content in chia seed and low carbohydrates, the seed has indicated the capability to lower appetite and increase satiety [114]. Research has shown that chia consumption promotes weight loss, C-reactive protein raises adiponectin and reduces waist circumference [21]. The fat content reduces significantly when one consumes chia foods [104]. In other studies have Chia fibre can be fermented in one's gut, resulting in the creation of short-chain fatty acids (SCFAs) and improve colon health [112], [115], [116].

\section{F. Relieve Dry Skin}

A healthy and hydrated skin comprises a rich layer of lipids; stratum lucidum that seal in moisture, moisturising the skin. When the layer is compromised or low in lipids, moisture can easily escape from the skin and lead to skin dryness [117], [118].

Oil from Chia seed is rich in omega- 6 fatty acids, linoleic acid, and omega-fatty acid ALA. These two fatty acids have proven to aid in reinstating the skins moisture layer, particularly with persons with dry skin conditions such as psoriasis and atopic dermatitis [119]-[122].

A small randomised study was conducted, where two participants groups with a dry skin condition; five healthy individuals and five with itchy skin as a result of diabetes or kidney disease applied their skins with $4 \%$ chia seed oil to their dry skins for 8 weeks [123]. After the 8 weeks, the researchers observed a significant improvement in their dry skin conditions. This study demonstrated the possible advantage of chia seeds oil in relieving dry skin [123]. In order to enjoy the full benefits of chia seeds on dry skins, it is advisable to apply your skin immediately after bathing or showering is during this time when the skin absorbs water at best [124].

\section{G. Prevent Premature Ageing of the Skin}

Chia seeds have been used as a major ingredient in skin care products because of high levels of fatty acids. Chia seed is specifically rich in alpha-linolenic acid (ALA), stearic acid and oleic acid [3], [53], [125].

Besides its typical application, diets that are rich in fatty acids are associated with protection from ultraviolet (UV) rays, healthier and hydrated skin that decreases the presence of fine lines [126]-[128]. Thus, taking food grade chia seed oil and using its skincare products help the skin look youthful.

\section{H. Reduce Blood Sugar Levels}

Untreated type 2 diabetes has been related to high fasting blood sugar levels, which later may lead to increased risks of chronic illnesses such as heart diseases [129]. Temporary blood sugar spikes after meals may have adverse effects later on if they occur on a regular basis [130].

Animal studies have proved Chia seeds to elevate insulin sensitivity and regulate blood sugar, maintaining blood sugar levels after meals [97], [102], [131]. Human studies have supported this by demonstrating that taking bread with chia seed reduces the after-meal rise in blood sugar than bread without chia seeds [132], [133]. After taking a high-carb meal, chia seeds may reduce the risk of high blood sugar, helpful for persons with type-2 diabetes.

\section{PHYSIOCHEMICAL PROPERTIES AND APPLICATIONS OF CHIA SEED}

Chia seed structure and physical properties are affected mainly by moisture content. Researchers have studied and analysed the physical properties of chia seeds [74]. White chia seeds contain a moisture content of $7.2 \%$, while black seeds contain $6.6 \%$ [134]. The white seed has lesser bulk density than the black ones due to their bigger size. Bulk density shows transport in addition to storage capacitance of the product. There have been no substantial variations between the porosity and actual density of both white and black chia seeds [9].

TABLE V: Showing Moisture-DePEndent of Physical Properties of

\begin{tabular}{ccc}
\multicolumn{3}{c}{ BLACK AND WHITE CHIA SEEDS } \\
\hline Physical property & White seeds & Black seeds \\
\hline True density $\left(\mathrm{g} / \mathrm{cm}^{2}\right)$ & 0.999 & 1.009 \\
Bulk density $\left(\mathrm{g} / \mathrm{cm}^{2}\right)$ & 0.667 & 0.772 \\
Porosity $(\%)$ & 33.1 & 28.2 \\
\hline
\end{tabular}

Source [9]

When chia seeds are immersed in water, they form gelatinous mass attributed to large quantities of gums and mucilage [135]. The seeds can captivate moisture up to 12 times their weight [74]. This feature makes it important in the food industry. Soluble fibre promotes gut health as it extends the gastrointestinal change period that helps enhance digestion. Antioxidants in dry chia seed make them last longer as it prevents autoxidation of fatty acids. Chia seed mucilage contains $71.22 \%$ polysaccharides [136]. The mucilage is extracted by hydrating the entire seed at $20{ }^{\circ} \mathrm{C}$ for two hours in the 40:1 water and seed ratio. The gelatinous solution is produced after hydration, then gathered, dried, and reserved at $50{ }^{\circ} \mathrm{C}$ for about ten hours in a convection air heat furnace. The dried mucilage and seed are separated by using a 40-mesh screen through the abrasion method [78]. Removed mucilage contains a moisture content of 37 times its mass on hydration, indicating water-holding abilities. At a 
low concentration of $0.3 \%$, the mucilage can form a highly viscous solution [78]. Chia mucilage solubility is $100 \%$ when examined at various concentrations such as $0.5 \%, 0.25 \%$, and $0.15 \%$ under temperatures of $90{ }^{\circ} \mathrm{C}, 70{ }^{\circ} \mathrm{C}, 60{ }^{\circ} \mathrm{C}$, and $30{ }^{\circ} \mathrm{C}$ and different centrifugation of $2000 \mathrm{~g}$ and $800 \mathrm{~g}$ conditions [78], [136], [137]. Chia mucilage is applied as a stabiliser and emulsifier [76]. Extracted mucilage improves and helps sustain the quality of ice cream during storage [136].

Protein fractions from chia flour formed through the dry fractionation procedure contain good emulsifying characteristics [138], where 95\% emulsion stability of chia seed is higher at alkaline $\mathrm{pH}$. Chia seed gel has a high water holding capacity (266 g), (emulsion stability (6\%), and oil holding capacity (58.6 g) compared to other grains [74]. Chia flour gel can be utilised as a thickening agent due to its valuable characteristics and high omega- 3 and omega- 6 fatty acids [139], [140]. Chia gel has freeze-thaw stability making it potential for use in frozen products. Several food products have been made by use of chia seed or chia flour. The products do not show distinctions in the physical and sensory properties such as overall liking, flavour, appearance, and colour. The use of chia flour in bread-making instead of wheat flour has reduced saturated fatty acid from $27 \%$ to $24 \%$ content [141]-[143]. Bread made with chia seeds or flour provides fibre and omega-3 fatty acids [76]. Chia bread is more nutritious and utilised as a functional food. Adding whole chia flour and vital gluten in dough making for the functional products development shows that adding (10\%) chia flour and (2\%) vital gluten increases the protein content (19\%), lipids (26\%), and ash content (11\%) compared to standard bread concentrations [144]. The chia bread is denser as the whole chia flour lowers the protein network.

\section{APPLICATION OF CHIA SEEDS AND DERIVED PRODUCTS}

Several studies have been done on chia seeds. In the food industry, chia seed has been applied in various forms such as whole, oil, ground, or gel [136], [141]. Chia seed intake is recommended to be a $48 \%$ daily allowance according to the United States dietary guideline 2018. Chia seeds are added as supplements into food products such as pasta, cereals, snacks, biscuits, or cakes [145]. Chia seeds can be used as substitutes due to their hydrophilic characteristics for fats and eggs [146], [147]. Chia absorbs twelve times their weight when soaked in water. Chia gels can be utilised as a replacement for eggs or oils in baked items [81]. Chia oil can replace $25 \%$ of eggs in cakes. Butter can be fortified with Chia to increase the nutritional value [136]. Chia mucilage from chia seeds is utilised as a functional coating with enhanced functional characteristics.

Chia mucilage has been applied as a stabiliser, emulsifier, suspending agent, binder, or adhesives due to its viscosity and water holding capabilities [136]. Chia mucilage is the source of polysaccharides and is used to produce polymer blends for consumable coating and films. Edible films can be utilised to replace synthetic packaging [136]. Mucilage from the brittle film; hence the addition of plasticisers is required to obtain the mechanical properties of the edible films. Polyols can be applied to escalate the workability and elasticity of films. Chia seeds are the critical factor because their dietary fibre is obtained from fibre fraction by water. The chemical composition derived characteristics and chemical composition determines the necessity of a polysaccharide in the pharmaceutical and food industries [148]. Chia gum contains a fat content of $26.2 \%$, and if fat extraction is conducted, two-part are obtained: gum with fat and defatted gum. The defatted gum contains high protein, carbohydrates, and ash content [149].

Chia seeds can be utilised in pharmaceutical applications. Chia oil bilayer emulsions contain possibilities of omega-3 fatty acids used in pharmaceutical use as the emulsions can be exposed to the drying procedure to get powder [136]. Chia oil is amalgamated into oil-in-water suspensions as an omega-3 fatty acids supply structure. Chia oil-in-water suspensions have low primary and secondary oxidation effects. Alpha-linolenic acid is used to produce biochemical compounds such as thromboxane or leukotrienes linked to various physiological uses in the body. The omega- 3 fatty acid can inhibit sodium and calcium pathways dysfunctions, enhancing the parasympathetic tone and protecting ventricular arrhythmia [150].

\section{ACKNOWLEDGMENT}

The review was carried at the Institute of Food Bioresources Technology, Dedan Kimathi University of Technology, Kenya.

\section{DISCLOSURE STATEMENT}

The authors declare that there is no conflict of interest regarding the publication of this paper.

\section{FUNDING}

This work was supported by the National Research Fund, Kenya.

\section{COMPLIANCE WITH ETHICS REQUIREMENTS}

This article does not contain any studies with animal and human subjects.

\section{AUTHOR's CONTRIBUTION}

Both authors were responsible for the overall concept, data collection, analysis. Joseph performed manuscript writing.

\section{REFERENCES}

[1] Ayerza R \& Coates W. Chia: rediscovering a forgotten crop of the Aztecs, 2005. books.google.com.

[2] Capitani MI, Spotorno V, Nolasco SM \& Tomás MC. Physicochemical and functional characterization of by-products from chia (Salvia hispanica L.) seeds of Argentina. LWT - Food Science and Technology 2012; 45, 94-102.

[3] Knez Hrnčič M, Ivanovski M, Cör D \& Knez Ž. Chia Seeds (Salvia hispanica L.): An Overview-Phytochemical Profile, Isolation Methods, and Application. Molecules 2019; Dec 18;25(1):11.

[4] Al-Zorfi MJA \& Al-Obaidi LFH. Study the Optimal Conditions for the Production of Protein Isolates from Chia Seeds. Annals of the Romanian Society for 2021; 25(3): 4400-4410.

[5] Fortino MA, Oliva ME, Rodriguez S, Lombardo YB \& Chicco A Could post-weaning dietary chia seed mitigate the development of dyslipidemia, liver steatosis and altered glucose homeostasis in 
offspring exposed to a sucrose-rich diet from utero to adulthood? Prostaglandins Leukot Essent Fatty Acids, 2017; 116:19-26.

[6] Jamboonsri W, Phillips TD, Geneve RL, Cahill JP \& Hildebrand DF Extending the range of an ancient crop, Salvia hispanica L.- - new $\omega 3$ source. Genet. Resour. Crop Evol. 2012; 59:171-178.

[7] Ayerza R. The seed's protein and oil content, fatty acid composition, and growing cycle length of a single genotype of chia (Salvia hispanica L.) as affected by environmental factors. J. Oleo Sci., 2009; 58:347354.

[8] Martínez-Cruz O \& Paredes-López O. Phytochemical profile and nutraceutical potential of chia seeds (Salvia hispanica L.) by ultra high performance liquid chromatography. J. Chromatogr. A, 2014; 1346 43-48.

[9] Porras-Loaiza P, Jiménez-Munguía MT, Sosa-Morales ME, Palou E \& López-Malo A. Physical properties, chemical characterization and fatty acid composition of Mexican chia ( Salvia hispanica L.) seeds. Int. J. Food Sci. Technol., 2014; 49:571-577.

[10] Báez RV \& Rodas MH. Vegetable oils rich in alpha linolenic acid incremen the paticn-3 LCPUFA, modulating the fatty acid metabolism and antioxidant response in rats. Prostaglandins Leukot Essent Fatty Acids, 2016 Aug;111:25-35.

[11] Valdivia-López MÁ \& Tecante A. Chia (Salvia hispanica): A Review of Native Mexican Seed and its Nutritional and Functional Properties. Advances in Food and Nutrition Research, 2015; 75:53-75.

[12] Aggarwal BB \& Shishodia S. Molecular targets of dietary agents for prevention and therapy of cancer. Biochem. Pharmacol. 2006; 71, 1397-1421.

[13] Ixtaina VY, Martínez ML, Spotorno V, Mateo CM, Maestri DM, Diehl BWK, Nolasco SM \& Tomás MC. Characterization of chia seed oils obtained by pressing and solvent extraction. Journal of Food Composition and Analysis, 2011; 24, 166-174.

[14] Reyes-Caudillo E, Tecante A \& Valdivia-López MA. Dietary fibre content and antioxidant activity of phenolic compounds present in Mexican chia (Salvia hispanica L.) seeds. Food Chem. 2008; 107, 656663.

[15] Ashura K-K, Lillian DK, Oscar K \& Leonard MPR. Nutritional, health benefits and usage of chia seeds (Salvia hispanica): A review. Afr. J. Food Sci. 2021; 15, 48-59.

[16] Njeri V, Mburu M \& Koskei K. Mould Characterization and Mycotoxin Quantification of Chia Seeds (Salvia hispanica L.) Grown in Kenya. J. Food Res. 2019; 8, 119.

[17] Melo D, Machado TB \& Oliveira MBPP. Chia seeds: an ancient grain trending in modern human diets. Food Funct, 2019; 10, 3068-3089.

[18] Grimes SJ, Capezzone F, Nkebiwe PM \& Graeff-Hönninger S Characterization and Evaluation of Salvia hispanica L. and Salvia columbariae Benth. Varieties for Their Cultivation in Southwestern Germany. Agronomy, 2020; 10, 2012.

[19] da Silva BP, Toledo RCL, Grancieri M, Moreira ME de C, Medina NR Silva RR, Costa NMB \& Martino HSD. Effects of chia (Salvia hispanica L.) on calcium bioavailability and inflammation in Wistar rats. Food Res. Int, 2019; 116, 592-599.

[20] Oyalo J \& Mburu M. Health Potential of Chia (Salvia hispanica L.) Seeds-Derived $\alpha$-linoleic Acid and $\alpha$-linolenic Acids: A Review. EJFOOD, 2021; 3, 5-10.

[21] Vuksan V, Jenkins AL, Brissette C, Choleva L, Jovanovski E, Gibbs AL, Bazinet RP, Au-Yeung F, Zurbau A, Ho HVT, Duvnjak L, Sievenpiper JL, Josse RG \& Hanna A. Salba-chia (Salvia hispanica L.) in the treatment of overweight and obese patients with type 2 diabetes: A double-blind randomized controlled trial. Nutr Metab Cardiovasc Dis, 2017; 27, 138-146.

[22] Ayerza (h) R \& Coates W. Protein content, oil content and fatty acid profiles as potential criteria to determine the origin of commercially grown chia (Salvia hispanica L.). Ind. Crops Prod., 2011; 34, 13661371.

[23] Panche AN, Diwan AD \& Chandra SR. Flavonoids: an overview. J. Nutr. Sci., 2016; 5, e47.

[24] Crozier A, Yokota T, Jaganath IB, Marks S, Saltmarsh M \& Clifford MN. Secondary Metabolites in Fruits, Vegetables, Beverages and Other Plant-based Dietary Components. In Plant Secondary Metabolites (Crozier A, Clifford MN, \& Ashihara H, eds), 2006; pp 208-302. Blackwell Publishing Ltd, Oxford, UK

[25] Das A. Advances in chia seed research. AIBM 5, 2017.

[26] Lee YK, Yuk DY, Lee JW, Lee SY, Ha TY, Oh KW, Yun YP \& Hong JT. (-)-Epigallocatechin-3-gallate prevents lipopolysaccharide-induced elevation of beta-amyloid generation and memory deficiency. Brain Res., 2009; 1250, 164-174.

[27] Havsteen BH. The biochemistry and medical significance of the flavonoids. Pharmacol. Ther., 2002; 96, 67-202.
[28] Liu I-M, Liou S-S, Lan T-W, Hsu F-L \& Cheng J-T. Myricetin as the active principle of Abelmoschus moschatus to lower plasma glucose in streptozotocin-induced diabetic rats. Planta Med., 2005; 71, 617-621.

[29] Alcântara MA, de Lima Brito Polari I, de Albuquerque Meireles BRL, de Lima AEA, da Silva Junior JC, de Andrade Vieira É, Dos Santos NA \& de Magalhães Cordeiro AMT. Effect of the solvent composition on the profile of phenolic compounds extracted from chia seeds. Food Chem., 2019; 275, 489-496.

[30] Tiwari R, Mohan M, Kasture S, Maxia A \& Ballero M. Cardioprotective potential of myricetin in isoproterenol-induced myocardial infarction in Wistar rats. Phytother Res, 2009; 23, 13611366.

[31] Ross JA \& Kasum CM. Dietary flavonoids: bioavailability, metabolic effects, and safety. Annu. Rev. Nutr., 2002; 22, 19-34.

[32] Halliwell B. Role of free radicals in the neurodegenerative diseases: therapeutic implications for antioxidant treatment. Drugs Aging, 2001; $18,685-716$

[33] Ong KC \& Khoo HE. Biological effects of myricetin. Gen Pharmacol, 1997; 29, 121-126.

[34] Chirumbolo S. The role of quercetin, flavonols and flavones in modulating inflammatory cell function. Inflamm Allergy Drug Targets, 2010; 9, 263-285

[35] Ananga A, Georgiev V \& Tsolova V. Manipulation and engineering of metabolic and biosynthetic pathway of plant polyphenols. Curr Pharm. Des., 2013; 19, 6186-6206.

[36] Anand David AV, Arulmoli R \& Parasuraman S. Overviews of biological importance of quercetin: A bioactive flavonoid. Pharmacogn. Rev., 2016; 10, 84-89.

[37] Rice-Evans C, Miller N \& Paganga G. Antioxidant properties of phenolic compounds. Trends Plant Sci., 1997; 2, 152-159.

[38] Hussain T, Tan B, Yin Y, Blachier F, Tossou MCB \& Rahu N. Oxidative stress and inflammation: what polyphenols can do for us? Oxid. Med. Cell. Longev., 2016, 7432797.

[39] García-Lafuente A, Guillamón E, Villares A, Rostagno MA \& Martínez JA. Flavonoids as anti-inflammatory agents: implications in cancer and cardiovascular disease. Inflamm Res, 2009; 58, 537-552.

[40] Li H, Ji H-S, Kang J-H, Shin D-H, Park H-Y, Choi M-S, Lee C-H, Lee I-K, Yun B-S \& Jeong T-S. Soy Leaf Extract Containing Kaempferol Glycosides and Pheophorbides Improves Glucose Homeostasis by Enhancing Pancreatic $\beta$-Cell Function and Suppressing Hepatic Lipid Accumulation in db/db Mice. J. Agric. Food Chem., 2015; 63, 71987210 .

[41] Haslam E. Practical polyphenolics: from structure to molecular recognition and physiological action, 1998. books.google.com.

[42] Haslam E. Natural polyphenols as drugs and medicines: potential modes of action. In Polyphenols, wine and health (Chèze $\mathrm{C}$, Vercauteren J, \& Verpoorte R, eds), 2001, pp. 1-47. Springer Netherlands, Dordrecht.

[43] Marín L, Gutiérrez-Del-Río I, Entrialgo-Cadierno R, Villar CJ \& Lombó F. De novo biosynthesis of myricetin, kaempferol and quercetin in Streptomyces albus and Streptomyces coelicolor. PLoS One, 2018, 13, $\mathrm{e} 0207278$

[44] Calderón-Montaño JM, Burgos-Morón E, Pérez-Guerrero C \& LópezLázaro M. A review on the dietary flavonoid kaempferol. Mini Rev. Med. Chem., 2011; 11, 298-344.

[45] Pei J, Chen A, Zhao L, Cao F, Ding G \& Xiao W. One-Pot Synthesis of Hyperoside by a Three-Enzyme Cascade Using a UDP-Galactose Regeneration System. J. Agric. Food Chem., 2017; 65, 6042-6048.

[46] Neuhouser ML. Dietary flavonoids and cancer risk: evidence from human population studies. Nutr Cancer, 2004; 50, 1-7.

[47] Weng C-J \& Yen G-C. Flavonoids, a ubiquitous dietary phenolic subclass, exert extensive in vitro anti-invasive and in vivo antimetastatic activities. Cancer Metastasis Rev., 2012; 31, 323-351.

[48] Imran M, Salehi B, Sharifi-Rad J, Aslam Gondal T, Saeed F, Imran A Shahbaz M, Tsouh Fokou PV, Umair Arshad M, Khan H, Guerreiro SG, Martins N \& Estevinho LM. Kaempferol: A key emphasis to its anticancer potential. Molecules, 2019, 24(12), 2277.

[49] Silva T, Oliveira C \& Borges F. Caffeic acid derivatives, analogs and applications: a patent review (2009-2013). Expert Opin. Ther. Pat. 2014; 24, 1257-1270.

[50] de Falco B, Amato M \& Lanzotti V. Chia seeds products: an overview. Phytochem. Rev., 2017; 16, 745-760.

[51] Rechner AR, Spencer JP, Kuhnle G, Hahn U \& Rice-Evans CA. Novel biomarkers of the metabolism of caffeic acid derivatives in vivo. Free Radic. Biol. Med., 2001; 30, 1213-1222.

[52] Naveed M, Hejazi V, Abbas M, Kamboh AA, Khan GJ, Shumzaid M, Ahmad F, Babazadeh D, FangFang X, Modarresi-Ghazani F, WenHua L \& XiaoHui Z. Chlorogenic acid (CGA): A pharmacological review and call for further research. Biomed. Pharmacother., 2018; 97, 67-74. 
[53] Ullah R, Nadeem M, Khalique A, Imran M, Mehmood S, Javid A \& Hussain J. Nutritional and therapeutic perspectives of Chia (Salvia hispanica L.): a review. J. Food Sci. Technol., 2016; 53, 1750-1758.

[54] Muñoz LA, Cobos A, Diaz O \& Aguilera JM. Chia Seed (Salvia hispanica ): An Ancient Grain and a New Functional Food. Food Reviews International, 2013; 29, 394-408.

[55] Mubarak A, Bondonno CP, Liu AH, Considine MJ, Rich L, Mas E, Croft KD \& Hodgson JM. Acute effects of chlorogenic acid on nitric oxide status, endothelial function, and blood pressure in healthy volunteers: a randomized trial. J. Agric. Food Chem., 2012; 60, 91309136.

[56] Thom E. The effect of chlorogenic acid enriched coffee on glucose absorption in healthy volunteers and its effect on body mass when used long-term in overweight and obese people. J Int Med Res, 2007; 35, 900-908.

[57] Park I, Ochiai R, Ogata H, Kayaba M, Hari S, Hibi M, Katsuragi Y, Satoh M \& Tokuyama K. Effects of subacute ingestion of chlorogenic acids on sleep architecture and energy metabolism through activity of the autonomic nervous system: a randomised, placebo-controlled, double-blinded cross-over trial. Br. J. Nutr., 2017; 117, 979-984.

[58] Tajik N, Tajik M, Mack I \& Enck P. The potential effects of chlorogenic acid, the main phenolic components in coffee, on health: a comprehensive review of the literature. Eur J Nutr, 2017; 56, 22152244.

[59] Benalla W \& Bellahcen S. Antidiabetic medicinal plants as a source of alpha glucosidase inhibitors. Curr Diabetes Revactions, 2010 Jul;6(4):247-54.

[60] Tunnicliffe JM, Eller LK, Reimer RA, Hittel DS \& Shearer J. Chlorogenic acid differentially affects postprandial glucose and glucose-dependent insulinotropic polypeptide response in rats. Appl Physiol Nutr Metab, 2011; 36, 650-659.

[61] Brglez Mojzer E, Knez Hrnčič M, Škerget M, Knez Ž \& Bren U. Polyphenols: extraction methods, antioxidative action, bioavailability and anticarcinogenic effects. Molecules, 11;21(7):901.

[62] Ayerza R. Seed composition of two chia (Salvia hispanica L.) genotypes which differ in seed color. Emirates Journal of Food \& Agriculture (EJFA), 2013; 25(7).

[63] Taga MS, Miller EE \& Pratt DE. Chia seeds as a source of natural lipid antioxidants. J Am Oil Chem Soc, 1984; 61, 928-931.

[64] Ikumi P, Mburu M \& Njoroge D. Chia (Salvia hispanica L.) - A Potential Crop for Food and Nutrition Security in Africa. J. Food Res., 2019; 8, 104

[65] Ayerza R \& Coates W. Chia seeds: New source of omega-3 fatty acids, natural antioxidants and dietary fiber. Food reviews international, 2013;11, 394-408.

[66] Mburu M, Paquet-Durand O, Hitzmann B \& Zettel V. Spectroscopic analysis of chia seeds. Sci. Rep., 2021; 11, 9253.

[67] Sandoval-Oliveros MR \& Paredes-López O. Isolation and characterization of proteins from chia seeds (Salvia hispanica L.). $J$. Agric. Food Chem., 2013; 61, 193-201.

[68] Ayerza R \& Coates W. Chia: rediscovering a forgotten crop of the Aztecs, 2005. books.google.com.

[69] Olivos-Lugo BL, Valdivia-López MÁ \& Tecante A. Thermal and Physicochemical Properties and Nutritional Value of the Protein Fraction of Mexican Chia Seed (Salvia hispanica L.). Food Science and Technology International, 2010; 16, 89-96.

[70] Skov AR, Toubro S, Rønn B, Holm L \& Astrup A. Randomized trial on protein vs carbohydrate in ad libitum fat reduced diet for the treatment of obesity. Int J Obes Relat Metab Disord, 1999; 23, 528536.

[71] Weigle DS, Breen PA, Matthys CC, Callahan HS, Meeuws KE, Burden VR \& Purnell JQ. A high-protein diet induces sustained reductions in appetite, ad libitum caloric intake, and body weight despite compensatory changes in diurnal plasma leptin and ghrelin concentrations. Am. J. Clin. Nutr., 2005; 82, 41-48.

[72] Leidy HJ, Tang M, Armstrong CLH, Martin CB \& Campbell WW. The effects of consuming frequent, higher protein meals on appetite and satiety during weight loss in overweight/obese men. Obesity (Silver Spring), 2011; 19, 818-824.

[73] Dhingra D, Michael M, Rajput H \& Patil RT. Dietary fibre in foods: a review. J. Food Sci. Technol., 2012; 49, 255-266.

[74] Muñoz LA, Cobos A, Diaz O \& Aguilera JM. Chia seeds: Microstructure, mucilage extraction and hydration. J. Food Eng., 2012, 108, 216-224.

[75] Srichuwong S, Curti D, Austin S, King R, Lamothe L \& GloriaHernandez H. Physicochemical properties and starch digestibility of whole grain sorghums, millet, quinoa and amaranth flours, as affected by starch and non-starch constituents. Food Chem., 2017; 233, 1-10.
[76] Coorey R, Grant A \& Jayasena V. Effects of chia flour incorporation on the nutritive quality and consumer acceptance of chips. J. Food Res. $2012 ; 1,85$.

[77] 77 Mohd Ali N, Yeap SK, Ho WY, Beh BK, Tan SW \& Tan SG (2012) The promising future of chia, Salvia hispanica L. J. Biomed. Biotechnol. 2012, 171956

[78] Suri S, Passi SJ \& Goyat J. Chia seed (Salvia hispanica L.) - A new age functional food. International Journal of Advanced Technology in Engineering and Science, 2016; 4(3): 286-299.

[79] Beltran-Orozco MC \& Romero MR. La Chia, Alimento Milenario, Departamento de Graduados e Investigacion en Alimentos. Food chem, 2003; 5(4): 23-25

[80] Muñoz L. Mucilage from chia seeds (Salvia hispanica) Microestructure, physico-chemical characterization and applications in food industry. PhD Thesis. Pontificia Universidad Catolica de Chile. 2012.

[81] Mburu MW. The Role of Chia Seeds Oil in Human Health: A Critical Review. European Journal of Agriculture and Food Sciences, 2021 3(4), 1-4.

[82] Gilbert K. The HD diet: achieve lifelong weight loss with chia seeds and nature's water-absorbent foods. 2014. books.google.com.

[83] Sargi SC, Silva BC, Santos HMC, Montanher PF, Boeing JS, Santos Júnior OO, Souza NE \& Visentainer JV. Antioxidant capacity and chemical composition in seeds rich in omega-3: chia, flax, and perilla. Food Science and Technology (Campinas), 2013; 33, 541-548.

[84] Coelho MS \& Salas MM. Chemical characterization of chia (Salvia hispanica L.) for use in food products. Journal of Food and Nutrition Research, 2014; 2(5):263-269.

[85] Ellulu MS. Obesity, cardiovascular disease, and role of vitamin C on inflammation: a review of facts and underlying mechanisms. Inflammopharmacology, 2017; 25, 313-328.

[86] Gramza-Michałowska A, Kobus-Cisowska J, Kmiecik D, Korczak J, Helak B, Dziedzic K \& Górecka D. Antioxidative potential, nutritional value and sensory profiles of confectionery fortified with green and yellow tea leaves (Camellia sinensis). Food Chem. 2016; 211, 448454.

[87] Rittmaster M. Antioxidants: The Unbiased Scientific Truth, EvidenceBased Health Benefits, and Important Facts. Available from https://www.healthinsiders.com/antioxidants.

[88] Khansari N, Shakiba Y \& Mahmoudi M. Chronic inflammation and oxidative stress as a major cause of age-related diseases and cancer. Recent Pat. Inflamm. Allergy Drug Discov., 2009; 3, 73-80.

[89] Vuksan V, Whitham D, Sievenpiper JL, Jenkins AL, Rogovik AL, Bazinet RP, Vidgen E \& Hanna A. Supplementation of conventional therapy with the novel grain Salba (Salvia hispanica L.) improves major and emerging cardiovascular risk factors in type 2 diabetes: results of a randomized controlled trial. Diabetes Care, 2007; 30 2804-2810.

[90] Hämäläinen M, Nieminen R \& Vuorela P. Anti-inflammatory effects of flavonoids: genistein, kaempferol, quercetin, and daidzein inhibit STAT-1 and NF-kappaB activations, whereas flavone, isorhamnetin, naringenin, and pelargonidin inhibit only NF-kappaB activation along with their inhibitory effect on iNOS expression and NO production in activated macrophages. Mediators Inflamm., 2007:45673.

[91] Spencer JPE. Flavonoids and brain health: multiple effects underpinned by common mechanisms. Genes Nutr, 2009; 4, 243-250.

[92] Liu C-M, Sun Y-Z, Sun J-M, Ma J-Q \& Cheng C. Protective role of quercetin against lead-induced inflammatory response in rat kidney through the ROS-mediated MAPKs and NF-кB pathway. Biochim. Biophys. Acta, 2012; 1820, 1693-1703.

[93] Wadsworth TL \& Koop DR. Effects of the wine polyphenolics quercetin and resveratrol on pro-inflammatory cytokine expression in RAW 264.7 macrophages. Biochem. Pharmacol., 1999; 57, 941-949.

[94] Boots AW, Haenen GRMM \& Bast A. Health effects of quercetin: from antioxidant to nutraceutical. Eur. J. Pharmacol., 2008; 585, 325-337.

[95] Coelho MS, Soares-Freitas RAM, Arêas JAG, Gandra EA \& SalasMellado M de LM. Peptides from Chia Present Antibacterial Activity and Inhibit Cholesterol Synthesis. Plant Foods Hum. Nutr., 2018; 73 101-107.

[96] Grancieri M, Martino HSD \& Gonzalez de Mejia E. Chia Seed (Salvia hispanica L.) as a Source of Proteins and Bioactive Peptides with Health Benefits: A Review. Comp. Rev. Food Sci. Food Safety, 2019; 18, 480-499.

[97] Poudyal H, Panchal SK, Waanders J, Ward L \& Brown L. Lipid redistribution by $\alpha$-linolenic acid-rich chia seed inhibits stearoyl-CoA desaturase- 1 and induces cardiac and hepatic protection in diet-induced obese rats. J. Nutr. Biochem., 2012; 23, 153-162.

[98] Nair CV, Suresh A \& Navaneetha S. Diet and Breast Cancer: A Review on Prolon Fast Mimicking Diet in the Treatment of Breast Cancer. Annals of R.S.C.B., 2021; 25(6):17666-17673. 
[99] Knekt P, Kumpulainen J, Järvinen R, Rissanen H, Heliövaara M, Reunanen A, Hakulinen T \& Aromaa A. Flavonoid intake and risk of chronic diseases. Am. J. Clin. Nutr., 2002; 76, 560-568.

[100]Fowokan AO, Sakakibara BM, Onsel N, Punthakee Z, Waddell C, Rosin M \& Lear SA. Correlates of elevated blood pressure in healthy children: a systematic review. Clin Obes, 2018; 8, 366-381.

[101] Ayerza R \& Coates W. Effect of dietary alpha-linolenic fatty acid derived from chia when fed as ground seed, whole seed and oil on lipid content and fatty acid composition of rat plasma. Ann Nutr Metab, 2007; 51, 27-34.

[102] Chicco AG, D'Alessandro ME, Hein GJ, Oliva ME \& Lombardo YB. Dietary chia seed (Salvia hispanica L.) rich in alpha-linolenic acid improves adiposity and normalises hypertriacylglycerolaemia and insulin resistance in dyslipaemic rats. Br. J. Nutr., 2009; 101, 41-50.

[103] Nieman DC, Gillitt N, Jin F, Henson DA, Kennerly K, Shanely RA, Ore B, Su M \& Schwartz S. Chia seed supplementation and disease risk factors in overweight women: a metabolomics investigation. J. Altern. Complement. Med. 2012; 18, 700-708.

[104] Toscano LT, da Silva CSO, Toscano LT, de Almeida AEM, Santos A da C \& Silva AS. Chia flour supplementation reduces blood pressure in hypertensive subjects. Plant Foods Hum. Nutr., 2014; 69, 392-398.

[105] de Souza Ferreira C, dd Sousa Fomes L de F, da Silva GES \& Rosa G Effect of chia seed (salvia hispanica 1.) consumption on cardiovascular risk factors in humans: a systematic review. Nutr. Hosp., 2015; 32, 1909-1918.

[106]Costantini L, Molinari R \& Merendino N. Effects of chia seed supplementation on biochemical markers of cardiometabolic diseases in spontaneously hypertensive rats. Acta Alimentaria, 2019; 48, 538545.

[107] Suzuki A, Yamamoto N, Jokura H, Yamamoto M, Fujii A, Tokimitsu I \& Saito I. Chlorogenic acid attenuates hypertension and improves endothelial function in spontaneously hypertensive rats. J. Hypertens., 2006; 24, 1065-1073.

[108]Suzuki A, Kagawa D, Fujii A, Ochiai R, Tokimitsu I \& Saito I. Shortand long-term effects of ferulic acid on blood pressure in spontaneously hypertensive rats. Am. J. Hypertens., 2002; 15, 351-357.

[109]Segura-Campos MR, Salazar-Vega IM, Chel-Guerrero LA \& Betancur-Ancona DA. Biological potential of chia (Salvia hispanica L.) protein hydrolysates and their incorporation into functional foods. LWT - Food Science and Technology, 2013; 50, 723-731.

[110] Marineli R da S, Moraes ÉA, Lenquiste SA, Godoy AT, Eberlin MN \& Maróstica Jr MR. Chemical characterization and antioxidant potential of Chilean chia seeds and oil (Salvia hispanica L.). LWT - Food Science and Technology, 2014; 59, 1304-1310.

[111]Zhao Y, Wang J, Ballevre O, Luo H \& Zhang W. Antihypertensive effects and mechanisms of chlorogenic acids. Hypertens Res, 2012; 35, 370-374.

[112] Marlett JA, McBurney MI, Slavin JL \& American Dietetic Association. Position of the American Dietetic Association: health implications of dietary fiber. J. Am. Diet. Assoc., 2002; 102, 993-1000.

[113]Alfredo V-O, Gabriel R-R, Luis C-G \& David B-A. Physicochemical properties of a fibrous fraction from chia (Salvia hispanica L.). $L W T$ Food Science and Technology, 2009; 42, 168-173.

[114]Ayaz A, Akyol A, Inan-Eroglu E, Kabasakal Cetin A, Samur G \& Akbiyik F. Chia seed (Salvia Hispanica L.) added yogurt reduces shortterm food intake and increases satiety: randomised controlled trial. Nutr Res Pract, 2017; 11, 412-418.

[115] Slavin J. Fiber and prebiotics: mechanisms and health benefits Nutrients, 2013; 5, 1417-1435.

[116] Guarner F \& Malagelada J-R. Gut flora in health and disease. Lancet, $2003 ; 361,512-519$

[117]Pappas A. Epidermal surface lipids. Dermatoendocrinol, 2009; 1, 72 76.

[118]Pons-Guiraud A. Dry skin in dermatology: a complex physiopathology. J. Eur. Acad. Dermatol. Venereol., 2007; 21 Suppl 2, 1-4.

[119]Lin T-K, Zhong L \& Santiago JL. Anti-Inflammatory and Skin Barrier Repair Effects of Topical Application of Some Plant Oils. Int. J. Mol. Sci. 2017; 9(1): 70

[120] Moore EM, Wagner C \& Komarnytsky S. The enigma of bioactivity and toxicity of botanical oils for skin care. Front. Pharmacol., 2020; 11,785 .

[121]Nasrollahi SA, Ayatollahi A, Yazdanparast T, Samadi A, Hosseini H, Shamsipour M, Akhlaghi AA, Yadangi S, Abels C \& Firooz A Comparison of linoleic acid-containing water-in-oil emulsion with urea-containing water-in-oil emulsion in the treatment of atopic dermatitis: a randomized clinical trial. Clin. Cosmet. Investig. Dermatol., 2018; 11, 21-28.

[122] Rosso JD, Zeichner J, Alexis A, Cohen D \& Berson D. Understanding the epidermal barrier in healthy and compromised skin: clinically relevant information for the dermatology practitioner: proceedings of an expert panel roundtable meeting. J. Clin. Aesthet. Dermatol., 2016; 9, S2-S8.

[123] Jeong SK, Park HJ, Park BD \& Kim I-H. Effectiveness of Topical Chia Seed Oil on Pruritus of End-stage Renal Disease (ESRD) Patients and Healthy Volunteers. Ann. Dermatol., 2010; 22, 143-148.

[124]Purnamawati S, Indrastuti N, Danarti R \& Saefudin T. The role of moisturizers in addressing various kinds of dermatitis: A review. Clin Med Res, 2017; 15, 75-87.

[125]Kulczyński B, Kobus-Cisowska J, Taczanowski M, Kmiecik D \& Gramza-Michałowska A. The Chemical Composition and Nutritiona Value of Chia Seeds-Current State of Knowledge. Nutrients, 2019 Jun; 11(6): 1242.

[126] McCusker MM \& Grant-Kels JM. Healing fats of the skin: the structural and immunologic roles of the omega- 6 and omega-3 fatty acids. Clin Dermatol, 2010; 28, 440-451.

[127] Gammone MA, Riccioni G, Parrinello G \& D’Orazio N. Omega-3 Polyunsaturated Fatty Acids: Benefits and Endpoints in Sport Nutrients. 2019 Jan; 11(1): 46.

[128]Balić A, Vlašić D, Žužul K, Marinović B \& Bukvić Mokos Z. Omega3 Versus Omega-6 Polyunsaturated Fatty Acids in the Prevention and Treatment of Inflammatory Skin Diseases. Int J Mol Sci., 2020 Jan 23;21(3):741.

[129] Snell-Bergeon JK \& Wadwa RP. Hypoglycemia, diabetes, and cardiovascular disease. Diabetes Technol Ther, 2012; 14 Suppl 1, S518

[130]Ceriello A. Point: postprandial glucose levels are a clinically important treatment target. Diabetes Care, 2010; 33, 1905-1907.

[131] Oliva ME, Ferreira MR, Chicco A \& Lombardo YB. Dietary Salba (Salvia hispanica L) seed rich in $\alpha$-linolenic acid improves adipose tissue dysfunction and the altered skeletal muscle glucose and lipid metabolism in dyslipidemic insulin-resistant rats. Prostaglandins, Leukotrienes and Essential Fatty Acids, 2013; 89, 279-289.

[132] Vuksan V, Jenkins AL, Dias AG, Lee AS, Jovanovski E, Rogovik AL \& Hanna A. Reduction in postprandial glucose excursion and prolongation of satiety: possible explanation of the long-term effects of whole grain Salba (Salvia Hispanica L.). Eur. J. Clin. Nutr. 2010; 64, 436-438.

[133] Ho H, Lee AS, Jovanovski E, Jenkins AL, Desouza R \& Vuksan. Effect of whole and ground Salba seeds (Salvia Hispanica L.) on postprandial glycemia in healthy volunteers: a randomized controlled, doseresponse trial. Eur. J. Clin. Nutr.; 2013; 67, 786-788.

[134]Ixtaina VY, Nolasco SM \& Tomás MC. Physical properties of chia (Salvia hispanica L.) seeds. Ind. Crops Prod., 2008; 28, 286-293.

[135]Melina V \& Forest J. Cooking Vegan: Healthful, Delicious, and Easy 2012. books.google.com.

[136]Campos BE, Dias Ruivo T, da Silva Scapim MR, Madrona GS \& de C. Bergamasco R. Optimization of the mucilage extraction process from chia seeds and application in ice cream as a stabilizer and emulsifier. LWT - Food Science and Technology, 2016; 65, 874-883.

[137]Capitani MI, Ixtaina VY, Nolasco SM \& Tomás MC. Microstructure, chemical composition and mucilage exudation of chia (Salvia hispanica L.) nutlets from Argentina. J. Sci. Food Agric., 2013; 93, 3856-3862.

[138] Vázquez-Ovando A, Betancur-Ancona D \& Chel-Guerrero L. Physicochemical and functional properties of a protein-rich fraction produced by dry fractionation of chia seeds ( Salvia hispanica L.). CyTA - Journal of Food, 2013; 11, 75-80.

[139] Inglett GE, Chen D, Liu SX \& Lee S. Pasting and rheological properties of oat products dry-blended with ground chia seeds. LWT - Food Science and Technology, 2014; 55, 148-156.

[140]Botella-Martínez C, Pérez-Álvarez JÁ, Sayas-Barberá E, FernándezLópez J \& Viuda-Martos M. Assessment of Chemical, Physicochemical, and Lipid Stability Properties of Gelled Emulsions Elaborated with Different Oils Chia (Salvia hispanica L.) or Hemp (Cannabis sativa L.) and Pseudocereals. Foods, 2021 Jun 24;10(7):1463

[141] Costantini L, Lukšič L, Molinari R, Kreft I, Bonafaccia G, Manzi L \& Merendino N. Development of gluten-free bread using tartary buckwheat and chia flour rich in flavonoids and omega-3 fatty acids as ingredients. Food Chem.; 2014; 165, 232-240.

[142]Zettel V \& Hitzmann B. Applications of chia (Salvia hispanica L.) in food products. Trends Food Sci. Technol.; 2018; 80, 43-50.

[143] Goyat J, Passi SJ, Suri S \& Dutta H. Development of Chia (Salvia hispanica, L.) and Quinoa (Chenopodium quinoa, L.) Seed Flour Substituted Cookies- Physicochemical, Nutritional and Storage Studies. Curr. Res. Nutr. Food Sci. 2018; 6, 757-769.

[144]Coelho MS \& Salas-Mellado M de las M. Effects of substituting chia (Salvia hispanica L.) flour or seeds for wheat flour on the quality of the bread. LWT - Food Science and Technology, 2015; 60, 729-736. 
[145]Felisberto MHF, Wahanik AL, Gomes-Ruffi CR, Clerici MTPS, Chang YK \& Steel CJ. Use of chia (Salvia hispanica L.) mucilage gel to reduce fat in pound cakes. LWT - Food Science and Technology, 2015, 63, 1049-1055.

[146]Ding Y, Lin H-W, Lin Y-L, Yang D-J, Yu Y-S, Chen J-W, Wang S-Y \& Chen Y-C. Nutritional composition in the chia seed and its processing properties on restructured ham-like products. Journal of Food and Drug Analysis, 2018; 26(1); 124-134.

[147]Gallo LR dos R, Assunção Botelho RB, Ginani VC, de Lacerda de Oliveira L, Riquette RFR \& Leandro E dos S. Chia ( Salvia hispanica $L$.) Gel as Egg Replacer in Chocolate Cakes: Applicability and Microbial and Sensory Qualities After Storage. Journal of Culinary Science \& Technology, 2020; 18, 29-39.

[148]Luna Pizarro P, Almeida EL, Coelho AS, Sammán NC, Hubinger MD \& Chang YK. Functional bread with n-3 alpha linolenic acid from whole chia (Salvia hispanica L.) flour. J. Food Sci. Technol., 2015; 52, 4475-4482.

[149]Segura-Campos MR \& Ciau-Solís N. Chemical and functional properties of chia seed (Salvia hispanica L.) gum. Int J Food Sci, 2014;2014:241053.

[150]Teoh SL, Lai NM, Vanichkulpitak P, Vuksan V, Ho H \& Chaiyakunapruk N. Clinical evidence on dietary supplementation with chia seed (Salvia hispanica L.): a systematic review and meta-analysis. Nutr. Rev., 2018; 76, 219-242. 